\title{
Chemical composition and
} hypocholesterolemic effect of milk kefir and water kefir in Wistar rats

\section{Composição química e efeito}

hipocolesterolêmico

do kefir de leite e do kefir de água

em ratos Wistar

Arthur ROCHA-GOMES 1 (ID) 0000-0002-2494-3113

Amanda ESCOBAR ${ }^{1}$ (D) 0000-0003-0571-7409

Jéssica Silva SOARES1 (iD) 0000-0002-5809-7998

Alexandre Alves da SILVA ${ }^{1}$ (D) 0000-0002-1177-0399

Nísia Andrade Villela DESSIMONI-PINTO' ${ }^{1}$ (D) 0000-0002-7485-3757

Tania Regina RIUL1 (ID) 0000-0003-0393-2236

\section{A B S T R A C T}

\section{Objective}

To compare the effects of fermented kefir on the nutritional, physiological, and biochemical parameters of rats.

\section{Methods}

Grains of milk kefir (whole and skimmed) and water kefir (brown sugar) were used. The chemical composition analysis was performed on substrates and fermented beverages. The rats were evaluated for weight gain, body

\footnotetext{
${ }^{1}$ Universidade Federal dos Vales do Jequitinhonha e Mucuri, Faculdade de Ciências Biológicas e da Saúde, Departamento de Nutrição. Rod. MGT 367 - Km 583, Campus JK, n.5000, Alto da Jacuba, 39100-000, Diamantina, MG, Brasil. Correspondência para/Correspondence to: TR RIUL. E-mail: <taniriul@yahoo.com.br>.
}

Como citar este artigo/How to cite this article

Rocha-Gomes A, Escobar A, Soares JS, Silva AA, Dessimoni-Pinto NAV, Riul TR. Chemical composition and hypocholesterolemic effect of milk kefir and water kefir in Wistar rats. Rev Nutr. 2018;31(2):137-45. http://dx.doi.org/10.1590/1678-98652018 000200001 
mass index, as well as their food, water, kefir, and calorie intake. We also evaluated their energy efficiency coefficient, weight of organs, in addition to their serum, and hepatic biochemistry.

\section{Results}

Fermentation increased the acid content index owing to degradation of lactose and brown sugar. The animals consumed more kefir, reducing the intake of chow and water. Kefir did not alter body and organ weight, while improving the lipid profile.

\section{Conclusion}

Water kefir with brown sugar was more effective in improving the lipid profile.

Keywords: Anticholesteremic. Brown sugar. Cholesterol. Kefir. Milk. Rats, Wistar.

\section{RE S U M O}

\section{Objetivo}

Este estudo tem como objetivo comparar os efeitos dos fermentados de kefir sobre parâmetros nutricionais, fisiológicos e bioquímicos de ratos.

\section{Métodos}

Foram utilizados grãos de kefir de leite (integral e desnatado) e de água (açúcar mascavo). A composição química foi realizada nos substratos e fermentados. Foram avaliados nos ratos: ganho de peso; índice de massa corporal; ingestão de ração, água, kefir e calorias; coeficiente de eficiência energética; peso dos órgãos; e bioquímica sérica e hepática.

\section{Resultados}

A fermentação elevou o índice de compostos ácidos a partir da degradação da lactose e do açúcar mascavo. Os animais consumiram mais kefir, diminuindo a ingestão de ração e água. O kefir não alterou o peso corporal e dos órgãos, melhorando ainda o perfil lipídico.

\section{Conclusão}

O kefir de água com açúcar mascavo foi mais eficaz na melhora do perfil lipídico.

Palavras-chave: Anticolesterêmicos. Açúcar mascavo. Colesterol. Grãos de Kefir. Leite. Ratos Wistar.

\section{NTRODUCTION}

With origins in the Caucasus Mountains, kefir is a symbiotic culture of microorganisms that include lactic acid bacteria and yeasts. It has the shape of a grain, consisting of a biomatrix of polysaccharides [1].

The "milk kefir" grains are irregular in size and shape, and they are white/yellow color. They produce a fermented beverage [2,3] that has the anti-inflammatory, antineoplastic, antioxidant, antibacterial, antifungal, immunomodulatory, and hypocholesterolemic properties [4]. The "water kefir" or "Tibico" grains are brownish color and produce a slightly acidic, refreshing beverage with medicinal properties also described in the literature $[5,6]$.

Hsieh et al. [5] found that, depending on the substrate or the type of grain used (milk or water), there are differences in the microbiota of the fermented beverages produced. These differences are related to the species found in each type of grain and the nutrients available in the substrates.

Because the two types of grains have distinct microbiota, the fermented beverages they produce can bring about different effects in vivo. Therefore, the aim of this study was to compare the effects of fermented milk kefir to the effects of fermented water kefir - using different 
substrates - on the nutritional, physiological, and biochemical parameters of rats.

\section{METHODS}

\section{Preparation of beverages and chemical analysis}

The kefir grains were obtained in the city of Diamantina (MG), and they were fermented in the Experimental Nutrition Laboratory of the Universidade Federal dos Vales do Jequitinhonha e Mucuri (LabNutrex - UFVJM).

The milk and water kefir grains (10\% $\mathrm{w} / \mathrm{v})$ were placed in glass containers containing (1) Whole Milk (WM), (2) Skim Milk (SM), both processed at ultra-high temperature (UHT), or (3) water mixed with Brown Sugar (BS). They were then incubated at $25 \pm 2^{\circ} \mathrm{C}$. After 48 hours, they were filtered to separate the kefir grains from the fermented beverages, which were stored at $0 \pm 2^{\circ} \mathrm{C}$.

We analyzed the potential of Hydrogen $(\mathrm{pH})$, Titratable Acidity (TA), moisture, ash, lipids, proteins, Soluble Solids (SS), lactose, carbohydrates, and energy $[7,8]$ of the substrates (WM, SM, and BS) as well as that of the fermented beverages produced via kefir's interaction With Whole Milk (KW), Skim Milk (KS), and Water With Brown Sugar (KB).

\section{Animals}

Male Wistar rats (70 days old) from LabNutrex - UFVJM were used. They were housed individually in conditions of natural moisture; temperature of $23 \pm 2^{\circ} \mathrm{C}$; and a 12 -hour cycle of light and darkness.

Euthanasia were carried out according to ethical principles [9], and the experiment was approved by the Comissão de Ética no Uso de Animais (Ethics Commission on the Use of Animals) (protocol 040/14).
The animals received ad libitum treatment for 42 days as follows: Control Group (C) - Food and water $(n=6)$; Whole Milk Kefir Group (KW) - Food, water, and fermented whole milk kefir $(n=6)$; Skim Milk Kefir Group (KS) - Food, water, and fermented skim milk kefir $(n=6)$; Water Kefir with Brown Sugar Group (KB) - Food, water, and fermented water kefir with brown sugar $(n=6)$.

Weight Gain (WG) was determined by calculating the difference between the animals' final weight and initial weight. Body Mass Index (BMI) was calculated by using the following ratio: body weight/body length [2].

The food, water, and fermented beverages were weighed/measured daily to obtain the Total Food Intake (TFI), Total Water Intake (TWI), and Total Kefir Intake (TKI).

We used the sum of caloric intake from food and caloric intake from fermented beverages to calculate total caloric intake (TCI). The Energy Efficiency Coefficient (EEC) was obtained from the ratio of weight gain/total caloric intake.

On the $42^{\text {nd }}$ day, the animals were anesthetized (xylazine 20mg/kg, ketamine $40 \mathrm{mg} / \mathrm{kg}$ ) and euthanized by exsanguination. The organs (spleen, heart, liver, kidneys, adrenal glands, and testicles) and abdominal fat (visceral, epididymal, and retroperitoneal) were weighed.

We collected $2 \mathrm{~mL}$ of blood from each rat to determine the total cholesterol, High Density Lipoprotein (HDL), glucose, and triglycerides according to the protocol set forth by the manufacturer of the kits (Labtest ${ }^{\circledR}$ ) used. The Low Density Lipoprotein (LDL) was calculated as described by Friedewald et al. [10], and the Atherogenic Index (Al) was calculated using the following formula: (Total cholesterol - HDL)/HDL [11].

The liver was dried in an oven at $105^{\circ} \mathrm{C}$ for 4 hours to evaluate lipids by extraction using an organic solvent; hepatic cholesterol and triglycerides levels were evaluated by using Labtest ${ }^{\circledR}$ kits $[12,13]$.

The data were submitted to variance analysis (ANOVA) according to the NewmanKeuls test $(p<0.05)$ when necessary. 


\section{RESULTS AND DISCUSSION}

Chemical analysis of the substrates and the fermented beverages is shown in Table 1. The fermented kefir beverages (KW, KS and KB) had lower $\mathrm{pH}$ than their substrates $(p<0.0001)$. As for titratable acidity, KS had the highest level, followed by KW and KB $(p<0.0001)$, and their substrates.

Milk kefir grains produced lower $\mathrm{pH}$ values and higher acidity $[2,14]$. Formulations containing lower amounts of fat (KS) undergo more chemical changes during storage. The increase in acidity is important to prevent the growth of pathogens $[14,15]$.

The acidity decreased and $\mathrm{pH}$ levels increased when water kefir grains were used [10]. This results from the production of organic acids (lactic, acetic, propionic, and butyric acid), phenols (caffeic, benzoic, gallic, and chlorogenic), ethanol, and $\mathrm{CO}_{2}[2,3,16]$.

Lactose in whole and skim milk decreased $(p<0.001)$ at the end of the fermentation process although milk is a source of lactose [17] (Table 1). Leite et al. [3] also observed the same result when using whole milk and kefir.

Microbiota containing greater amounts of bacteria than yeasts produce lactic acid from lactose [4]. Therefore, we can conclude that lactose in whole milk and skim milk is consumed during the formation of lactic acid.

Fermented $\mathrm{KB}$ had greater moisture $(p<0.01)$, while $\mathrm{KS}$ and $\mathrm{KW}$ did not differ from their substrates. With regard to the values of soluble solids, the substrates had higher values $(p<0.001)$, and the KB group had lower carbohydrate values $(p<0.05)$ (Table 1).

The level of soluble solids is related to the amount of sugars in the sample [18]. The reduction in SS found in fermented beverages was proportional to the reduction in lactose and brown sugar.

No differences were found for the ash, protein, and lipid content (Table 1). Although many species of Lactobacillus consume proteins from the medium [19], the microbiota used here consumed sugars only. The energy values indicated that WM and $\mathrm{KW}$ had the highest number of calories $(p<0.01)$, followed by SM and $\mathrm{KS}, \mathrm{BS}$, and $\mathrm{KB}$.

These results are directly related to the macronutrient content in the samples. BS had brown sugar as a source of energy, which, when consumed, resulted in low energy density in the $\mathrm{KB}$ that was produced.

The initial and final weight, weight gain, and BMl of the animals did not show any variation (Table 2$)$. Values of TFI $(p<0.05)$ and TWI $(p<0.0001)$ showed that the rats in group $C$ consumed the most feed and water. The rats in KB group had the highest TKI $(p<0.001)$.

The levels of TFI, TWI, and TKI indicate a high level of palatability of kefir, with decreased consumption of food and water. Consumption of fermented kefir leads to greater satiety, resulting in less food intake [20]. Because the fermented kefir has a high amount of moisture, consumption of fermented kefir also reduced the water intake.

The rats in $\mathrm{KW}$ group had the highest $\mathrm{TCl}$ values, followed by the rats in $\mathrm{KS}, \mathrm{C}$ and $\mathrm{KB}$ groups $(p<0.001)$. The EEC values were higher for the rats in Groups C and KB $(p<0.05)$ (Table 2).

Bacteria from milk kefir grains ( $L$. plantarum, L. acidophilus, L. kefiri) added to animal feed did not change dietary intake or dietary efficiency for weight gain [21].

The higher $\mathrm{TCl}$ of the rats in $\mathrm{KW}$ and KS groups is related to higher energy density. Proteins and fats increase the $\mathrm{TCl}$ because they are not degraded during the fermentation process. The microorganisms in kefir have proteinases that are capable of hydrolyzing the proteins in bovine milk, and this increases digestibility [22].

The greater digestibility of fermented $\mathrm{KW}$ and KS may have resulted in higher levels of consumption, which is also related to the increase in $\mathrm{TCl}$ and $\mathrm{EEC}$ for these groups. 


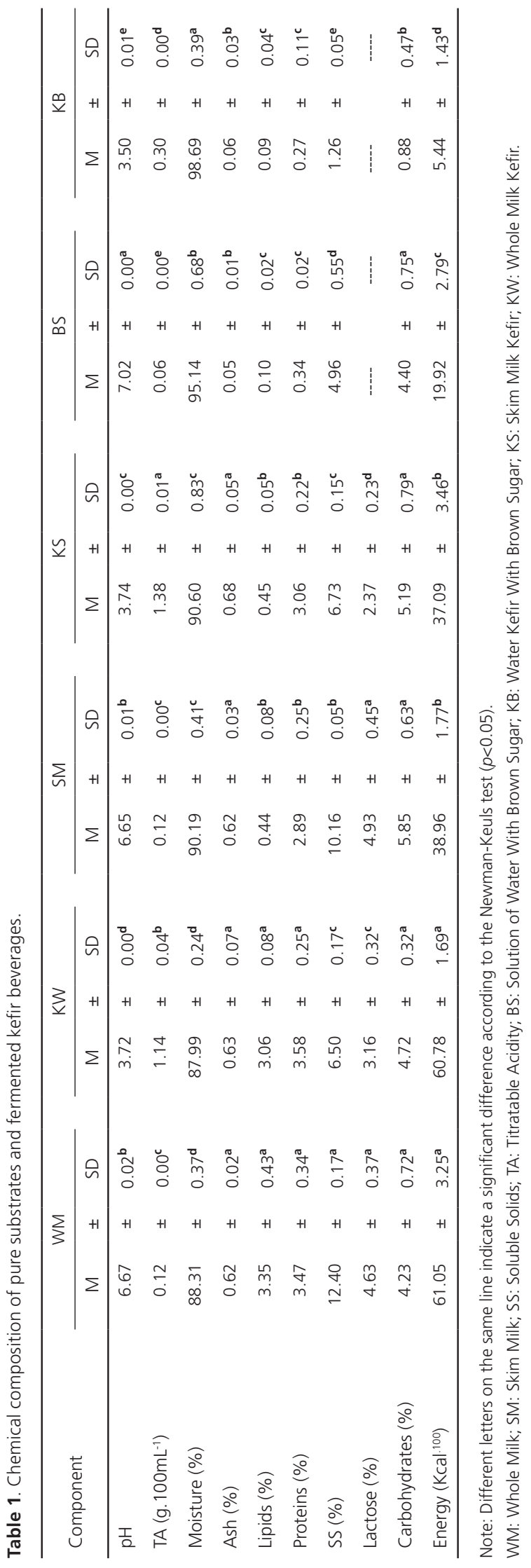


Leandro-Merhi et al. [23] stated that energy consumed is not the only factor associated with weight gain; it is also important to look at what kind of food is consumed.

Biochemistry findings of serum are shown in Table 3. The rats in $C$ and $\mathrm{KS}$ groups had the highest values for total cholesterol $(p<0.05)$. Rats in $\mathrm{KB}$ and $\mathrm{KS}$ had higher HDL than those in $C$ and KW $(p<0.001)$. $C$ had the highest value for LDL $(p<0.001)$.

The lower values of total cholesterol in the groups that received kefir show that kefir beverages are probiotic and have hypocholesterolemic effects [24] as demonstrated in other studies with milk kefir and water kefir $[25,26]$.

The reduction of plasma lipids with the consumption of probiotic food is due to the increase in fecal elimination of bile salts, which decreases the concentration of cholesterol in the blood [27].

There was an increase in HDL levels, and a decrease in LDL levels (Table 3 ) in rats that received kefir. Higher values of HDL and lower values of LDL have been found in animals treated with bacteria (L. plantarum and L. kefiri) obtained from grains of milk kefir $[21,28,29]$.

Table 2. Nutritional assessments of experimental groups.

\begin{tabular}{|c|c|c|c|c|c|c|c|c|c|c|c|c|}
\hline \multirow{2}{*}{ Variables } & \multicolumn{3}{|c|}{ C } & \multicolumn{3}{|c|}{ KW } & \multicolumn{3}{|c|}{ KS } & \multicolumn{3}{|c|}{$\mathrm{KB}$} \\
\hline & M & \pm & SD & M & \pm & SD & M & \pm & SD & M & \pm & SD \\
\hline Initial weight (g) & 162.87 & \pm & $11.58^{\mathrm{a}}$ & 160.15 & \pm & $11.98^{\mathrm{a}}$ & 171.30 & \pm & $8.03^{\mathrm{a}}$ & 166.42 & \pm & $18.28^{a}$ \\
\hline Final weigth (g) & 357.35 & \pm & $22.34^{a}$ & 359.17 & \pm & $8.53^{\mathrm{a}}$ & 367.27 & \pm & $29.96^{a}$ & 355.58 & \pm & $23.32^{\mathrm{a}}$ \\
\hline Weight gain (g) & 194.48 & \pm & $20.24^{a}$ & 199.02 & \pm & $7.77^{\mathrm{a}}$ & 195.97 & \pm & $28.42^{\mathrm{a}}$ & 189.16 & \pm & $36.00^{a}$ \\
\hline $\mathrm{BMI}\left(\mathrm{g} / \mathrm{cm}^{2}\right)$ & 14.55 & \pm & $0.73^{a}$ & 14.43 & \pm & $0.79^{a}$ & 14.78 & \pm & $0.19^{\mathrm{a}}$ & 14.58 & \pm & $1.01^{\mathrm{a}}$ \\
\hline TFI (g) & 163.06 & \pm & $12.82^{\mathrm{a}}$ & 145.20 & \pm & $4.76^{\mathbf{b}}$ & 153.43 & \pm & $9.86^{b}$ & 148.49 & \pm & $7.53^{b}$ \\
\hline TWI (mL) & 285.90 & \pm & $23.00^{a}$ & 158.76 & \pm & $14.72^{c}$ & 211.14 & \pm & $30.33^{\mathbf{b}}$ & 129.36 & \pm & $22.99^{d}$ \\
\hline TKI (mL) & ----- & & ----- & 354.90 & \pm & $61.48^{b}$ & 352.14 & \pm & $63.84^{b}$ & 567.68 & \pm & $141.48^{\mathrm{a}}$ \\
\hline TCI (kcal) & 597.11 & \pm & $46.95^{c}$ & 748.09 & \pm & $31.94^{\mathrm{a}}$ & 693.11 & \pm & $23.08^{\mathbf{b}}$ & 580.17 & \pm & $23.97^{c}$ \\
\hline $\mathrm{EEC}\left(\mathrm{g} / \mathrm{kcal} .100^{-1}\right)$ & 0.33 & \pm & $0.03^{a}$ & 0.27 & \pm & $0.02^{b}$ & 0.28 & \pm & $0.04^{b}$ & 0.32 & \pm & $0.05^{a}$ \\
\hline
\end{tabular}

Note: Different letters on the same line indicate a significant difference according to the Newman-Keuls test $(p<0.05)$.

C: Control; KW: Whole Milk Kefir; KS: Skim Milk Kefir; KB: Water Kefir With Brown Sugar; TFI: Total Food Intake; TWI: Total Water Intake; TKI: Total Kefir Intake; TCI: Total Caloric Intake; EEC: Energy Efficiency Coefficient; M: Media; SD: Standard Deviation.

Table 3. Serum biochemistry of experimental groups

\begin{tabular}{|c|c|c|c|c|c|c|c|c|c|c|c|c|}
\hline \multirow{2}{*}{ Variables } & \multicolumn{3}{|c|}{ C } & \multicolumn{3}{|c|}{ KW } & \multicolumn{3}{|c|}{ KS } & \multicolumn{3}{|c|}{ KB } \\
\hline & $M$ & \pm & SD & M & \pm & SD & $M$ & \pm & SD & M & \pm & SD \\
\hline Total cholesterol (mg/dL) & 57.83 & \pm & $9.72^{\mathrm{a}}$ & 43.51 & \pm & $6.83^{b}$ & 54.51 & \pm & $10.43^{\mathrm{ab}}$ & 45.65 & \pm & $8.59^{b}$ \\
\hline $\mathrm{HDL}(\mathrm{mg} / \mathrm{dL})$ & 22.56 & \pm & $2.28^{\mathbf{b}}$ & 22.15 & \pm & $3.91^{\mathrm{b}}$ & 28.81 & \pm & $4.01^{\mathrm{a}}$ & 31.22 & \pm & $3.55^{\mathrm{a}}$ \\
\hline LDL (mg/dL) & 24.92 & \pm & $3.09^{\mathrm{a}}$ & 17.50 & \pm & $2.37^{b}$ & 12.16 & \pm & $2.35^{c}$ & 7.41 & \pm & $4.55^{\mathrm{d}}$ \\
\hline Atherogenic index & 1.57 & \pm & $0.33^{\mathrm{a}}$ & 1.00 & \pm & $0.36^{\mathbf{b}}$ & 0.90 & \pm & $0.34^{\mathbf{b}}$ & 0.43 & \pm & $0.20^{c}$ \\
\hline Triglycerides (mg/dL) & 34.86 & \pm & $8.48^{\mathrm{a}}$ & 32.14 & \pm & $7.30^{\mathrm{a}}$ & 32.66 & \pm & $6.65^{a}$ & 26.09 & \pm & $8.42^{\mathrm{a}}$ \\
\hline Glucose (mg/dL) & 145.82 & \pm & $21.62^{a}$ & 170.13 & \pm & $22.16^{a}$ & 156.25 & \pm & $35.37^{a}$ & 153.33 & \pm & $32.13^{a}$ \\
\hline
\end{tabular}

Note: Different letters on the same line indicate a significant difference according to the Newman-Keuls test $(p<0.05)$.

C: Control; KW: Whole Milk Kefir; KS: Skim Milk Kefir; KB: Water Kefir With Brown Sugar; HDL: High Density Lipoprotein; LDL: Low Density Lipoprotein; M: Media; SD: Standard Deviation. 
Table 4. Liver biochemistry of experimental groups

\begin{tabular}{|c|c|c|c|c|c|c|c|c|c|c|c|c|}
\hline \multirow{2}{*}{ Variables } & \multicolumn{3}{|c|}{ C } & \multicolumn{3}{|c|}{ KW } & \multicolumn{3}{|c|}{ KS } & \multicolumn{3}{|c|}{ KB } \\
\hline & M & \pm & SD & M & \pm & SD & M & \pm & SD & M & \pm & SD \\
\hline Lipids (\%) & 13.42 & \pm & $3.00^{\mathrm{a}}$ & 12.93 & \pm & $1.83^{\mathrm{a}}$ & 12.70 & \pm & $3.85^{\mathrm{a}}$ & 15.47 & \pm & $4.33^{a}$ \\
\hline Cholesterol (mg/g) & 5.15 & \pm & $0.58^{\mathrm{a}}$ & 4.99 & \pm & $0.47^{\mathrm{a}}$ & 4.28 & \pm & $0.36^{\mathbf{b}}$ & 4.21 & \pm & $0.62^{b}$ \\
\hline Triglycerides (mg/g) & 5.15 & \pm & $0.82^{\mathrm{a}}$ & 4.25 & \pm & $1.55^{\mathrm{a}}$ & 3.83 & \pm & $1.20^{\mathrm{a}}$ & 3.72 & \pm & $0.94^{a}$ \\
\hline
\end{tabular}

Note: Different letters on the same line indicate a significant difference according to the Newman-Keuls test $(p<0.05)$.

C: Control; KW: Whole Milk Kefir; KS: Skim Milk Kefir; KB: Water Kefir With Brown Sugar; M: Media; SD: Standard Deviation.

Rats in Group $\mathrm{C}$ had the highest $\mathrm{Al}$ (Atherogenic Index), followed by rats in groups that received kefir $(p<0.001)$. Al is used to estimate the risk of developing atherosclerotic plaque, acute myocardial infarction, ischemia, and stroke $[11,30,31]$. The Al results show that all types of kefir have potential for the prevention of cardiovascular disease.

Although values for triglycerides [27,32] and glucose [25] decreased in some studies on probiotic microorganisms, we did not experience this in our study.

There was no change in organ weight or abdominal fat (results not shown). Similar outcomes were found in the literature $[24,33]$.

Hepatic results are shown in Table 4. Total hepatic cholesterol in rats belonging to groups $C$ and $\mathrm{KW}$ was higher than rats belonging to $\mathrm{KS}$ and $K B$ groups $(p<0.01)$. C57BL/6 mice treated for 4 weeks with milk kefir had decreased hepatic cholesterol [34].

The possible mechanism for this reduction in hepatic cholesterol may be the decreased expression of genes involved in the hepatic lipogenesis pathway, such as sterol regulatory element-binding proteins, fatty acid synthase, and acetyl-CoA carboxylase [34].

\section{CONCLUSION}

The kefir formulations were found to be high in acidity and low in sugars, with a consistent level of proteins and lipids. For the in vivo treatment, the fermented beverages do not alter animal development, leading to an improved in plasma and hepatic lipide profile.

Both types of grains studied had similar probiotic effects. However, water kefir with brown sugar was more effective in improving the lipid profile than milk kefir.

\section{A C KNOWLEDGEMENTS}

A ROCHA-GOMES, A ESCOBAR and JS SOARES participated in data collection, data analysis and interpretation, and writing of the article. AA SILVA contributed to the preparation of the article and data analysis. NAV DESSIMONI-PINTO and TR RIUL were responsible for the planning of the study, supervision of data analysis and data collection, and the final review of the article.

\section{REFERE N CES}

1. Bensmira M, Jiang B. Rheological characteristics and nutritional aspects of novel peanut based kefir beverages and whole milk kefir. Int Food Res J. 2012 [cited 2017 Sept 7];19(2):647-50. Available from: http://www.ifrj.upm.edu.my/19\%20(02)\%20 2012/(41)IFRJ-2012\%20Meriem.pdf

2. Magalhães $K T$, Dragone G, Pereira GVM, Oliveira $J M$, Domingues L, Teixeira JA, et al. Comparative study of the biochemical changes and volatile compound formations during the production of novel whey-based kefir beverages and traditional milk kefir. Food Chem. 2011;126(1):249-53. http:// dx.doi.org/10.1016/j.foodchem.2010.11.012

3. Leite AM, Leite DC, Del Aguila EM, Alvares TS, Peixoto RS, Miguel MA, et al. Microbiological and chemical characteristics of Brazilian kefir during fermentation and storage processes. J Dairy Sci. 2013;96(7):4149-59. http://dx.doi.org/10.3168/jds. 2012-6263 
4. Farnworth ER. Kefir: A complex probiotic. Food Sci Tech Bull Funct Foods. 2005 [cited 2017 Sept 7];2(1):1-17. Available from: http://www2.ufrb. edu.br/kefirdoreconcavo/images/artigos/artigo06. pdf

5. Hsieh $\mathrm{HH}$, Wang SY, Chen $\mathrm{TL}$, Huang $\mathrm{YL}$, Chen MJ. Effects of cow's and goat's milk as fermentation media on the microbial ecology of sugary kefir grains. Int J Food Microbiol. 2012;157(1):73-81. http://dx.doi.org/10.1016/j.ijfood micro.2012.04.014

6. Laureys D, De Vuyst L. Microbial species diversity, community dynamics, and metabolite kinetics of water kefir fermentation. Appl Environ Microbiol. 2014;80(8):2564-72. http://dx.doi.org/10.1128/ AEM.03978-13

7. Association of Official Analytical Chemists. Official methods of analysis of AOAC International. Arlington: AOAC International; 2000.

8. Srebernich SM, Gonçalves GMS, Ormenese RCSC, Ruffi CRG. Physico-chemical, sensory and nutritional characteristics of cereal bars with addition of acacia gum, inulin and sorbitol. Food Sci Techn. 2016;36(3):555-62. http://dx.doi.org/10. 1590/1678-457X.05416

9. Ministério da Ciência, Tecnologia e Inovação (Brasil). Conselho Nacional de Controle de Experimentação Animal. Diretrizes brasileira para o cuidado e a utilização de animais em atividade de ensino ou de pesquisa científica. Brasília: Concea; 2016.

10. Friedewald WT, Levy RI, Fredrickson DS. Estimation of the concentration of low-density lipoprotein cholesterol in plasma, without use of the preparative ultracentrifuge. Clin Chem. 1972 [cited 2017 Sept 7];18(6):499-502. Available from: http://clinchem.aaccjnls.org/content/clinchem/ 18/6/499.full.pdf

11. Touati S, Meziri F, Devaux S, Berthelot A, Touyz RM, Laurant $P$. Exercise reverses metabolic syndrome in high-fat diet-induced obese rats. Med Sci Sports Exerc. 2011;43(3):398-407. http://dx.doi.org/10. 1249/MSS.0b013e3181eeb12d

12. Instituto Adolfo Lutz. Normas Analíticas do Instituto Adolfo Lutz: métodos químicos e físicos para análise de alimentos. São Paulo: Imesp; 1985.

13. Eufrásio MR, Barcelos MFP, Souza RV, Abreu WC, Lima MAC, Pereira MCA. Efeitos de diferentes tipos de fibras sobre frações lipídicas do sangue e fígado de ratos Wistar. Ciênc Agrotec. 2009;33(6):1608-14. http://dx.doi.org/10.1590/ S1413-70542009000600021

14. Rocha DMUP, Martins JFL, Santos TSS, Moreira AVB. Labneh with probiotic properties produced from kefir: Development and sensory evaluation. Food Sci Technol. 2014;34(4):694-700. http://dx. doi.org/10.1590/1678-457x.6394

15. Almeida PF, Lannes SCS. Effects of chicken byproduct gelatin on the physicochemical properties and texture of chocolate spread. J Texture Stud. 2017;48:392-402. http://dx.doi.org/10.1111/jtxs.12 242

16. Sánchez-Maldonado AF, Schieber A， Gänzle MG. Structure-function relationships of the antibacterial activity of phenolic acids and their metabolism by lactic acid bacteria. J Appl Microbiol. 2011;111(5):1176-84. http://dx.doi. org/10.1111/j.1365-2672.2011.05141.x

17. Bosso A, Morioka LRI, Santos LF, Suguimoto $\mathrm{HH}$. Lactose hydrolysis potential and thermal stability of commercial $\beta$-galactosidase in UHT and skimmed milk. Food Sci Technol. 2016;36(1):15965. http://dx.doi.org/10.1590/1678-457X.0085

18. Santos OV, Lorenzo ND, Lannes SCS. Chemical, morphological, and thermogravimetric of Terminalia catappa Linn. Food Sci Technol. 2016;36(1):151-8. http://dx.doi.org/10.1590/1678-457X.0090

19. Pereira EPR, Faria JAF, Cavalcanti RN, Garcia RKA, Silva R, Esmerino EA, et al. Oxidative stress in probiotic Petit Suisse: Is the jabuticaba skin extract a potential option? Food Res Int. 2016;81:149-56. http://dx.doi.org/10.1016/j.foodres.2015.12.034

20. Carvalho MF, Costa MKME, Muniz GS, Castro RM, Nascimento E. Experimental diet based on the foods listed in the Family Budget Survey is more detrimental to growth than to the reflex development of rats. Rev Nutr. 2013;26(2):177-93. http://dx.doi.org/10.1590/S1415-52732013000 200006

21. Zheng Y, Lu Y, Wang J, Yang L, Pan C, Huang $Y$. Probiotic properties of Lactobacillus strains isolated from Tibetan kefir grains. PLoS One. 2013;8(7):e69868. http://dx.doi.org/10.1371/journal. pone.0069868

22. Dallas DC, Citerne F, Tian T, Silva VL, Kalanetra KM, Frese SA. Peptidomic analysis reveals proteolytic activity of kefir microorganisms on bovine milk proteins. Food Chem. 2016;197(Pt A):273-84. http://:doi.org/10.1016/j.foodchem.2015.10.116

23. Leandro-Merhi VA, Aquino JLB, Camargo JGT, Oliveira MRM. Energy and fat intake are not associated with abdominal adiposity. Nutr Clin Metab. 2013;27(3):117-22. http://dx.doi.org/10. 1016/j.nupar.2013.06.001

24 Liu J-R, Wang S-Y, Chen M-J, Chen H-L, Yueh $P-Y$, Lin C-W. Hypocholesterolaemic effects of milk-kefir and soyamilk-kefir in cholesterol-fed hamsters. Br J Nutr. 2006;95(5):939-46. http:// dx.doi.org/10.1079/BJN20061752 
25. Rosa DD, Peluzio MCG, Bueno TP, Canizares EV, Miranda LS, Dorbignyi BM. Evaluation of the subchronic toxicity of kefir by oral administration in Wistar rats. Nutr Hosp. 2014;29(6):1352-9. http://dx.doi.org/10.33 05/nh. 2014.29.6.7390

26. Alsayadi M, Jawfi YA, Belarbi M, Soualem-Mami Z, Merzouk H, Sari DC, et al. Evaluation of antihyperglycemic and anti-hyperlipidemic activities of water kefir as probiotic on Streptozotocin-induced diabetic Wistar rats. J Diabetes Mellitus. 2014 [cited 2017 Sept 7];4(2):85-95. Available from: http:// file.scirp.org/pdf/JDM_2014042114015646.pdf

27. Huang $Y$, Wu F, Wang $X$, Sui $Y$, Yang L, Wang J. Characterization of Lactobacillus plantarum Lp27 isolated from Tibetan kefir grains: A potential probiotic bacterium with cholesterol-lowering effects. J Dairy Sci. 2013;96(5):2816-25. http:// dx.doi.org/10.3168/jds.2012-6371

28. Xie N, Cui Y, Yin YN, Zhao X, Yang JW, Wang $Z G$, et al. Effects of two Lactobacillus strains on lipid metabolism and intestinal microflora in rats fed a high-cholesterol diet. BMC Complement Altern Med. 2011;11:53. http://dx.doi.org/10.11 86/1472-6882-11-53

29. Lollo PCB, Moura CS, Morato PN, Cruz AG, Castro WF, Betim $C B$, et al. Probiotic yogurt offers higher immune-protection than probiotic whey beverage. Food Res Int. 2013;54(1):118-24. http://dx.doi. org/10.1016/j.foodres.2013.06.003

30. Fernandes DC, Alves AM, Castro GSF, Jordão Junior A, Naves MMV. Effects of Baru almond and
Brazil nut against hyperlipidemia and oxidative stress In Vivo. J Food Res. 2015;4(4):38-46. https:// dx.doi.org/10.5539/jfr.v4n4p38

31. Moura CS, Lollo PCB, Morato PN, Esmerino EA, Margalho LP, Santos-Junior VA, et al. Assessment of antioxidant activity, lipid profile, general biochemical and immune system responses of Wistar rats fed with dairy dessert containing Lactobacillus acidophilus La-5. Food Res Int. 2016;90:275-80. http://dx.doi.org/10.1016/j.foodres. 2016.10.042

32. Salaj R, Stofilova J, Soltesova A, Hertelyova Z, Hijova E, Bertkova I, et al. The effects of two Lactobacillus plantarum strains on rat lipid metabolism receiving a high fat diet. Sci World J. 2013;2013:135142. http://dx.doi.org/10.1155/2013/135142

33. Owaga EE, Chen MJ, Chen WY, Chen CW, Hsieh $\mathrm{RH}$. Oral toxicity evaluation of kefir-isolated Lactobacillus kefiranofaciens M1 in SpragueDawley rats. Food Chem Toxicol. 2014;70:15762. http://dx.doi.org/10.1016/j.fct.2014.05.005

34. Chen HL, Tung YT, Tsai CL, Lai CW, Lai ZL, Tsai $\mathrm{HC}$, et al. Kefir improves fatty liver syndrome by inhibiting the lipogenesis pathway in leptindeficient ob/ob knockout mice. Int J Obes. 2014;38(9):1172-9. http://dx.doi.org/10.1038/ijo. 2013.236
Received: September 9, 2017

Final version: January 23, 2018 Approved: March 27, 2018 